
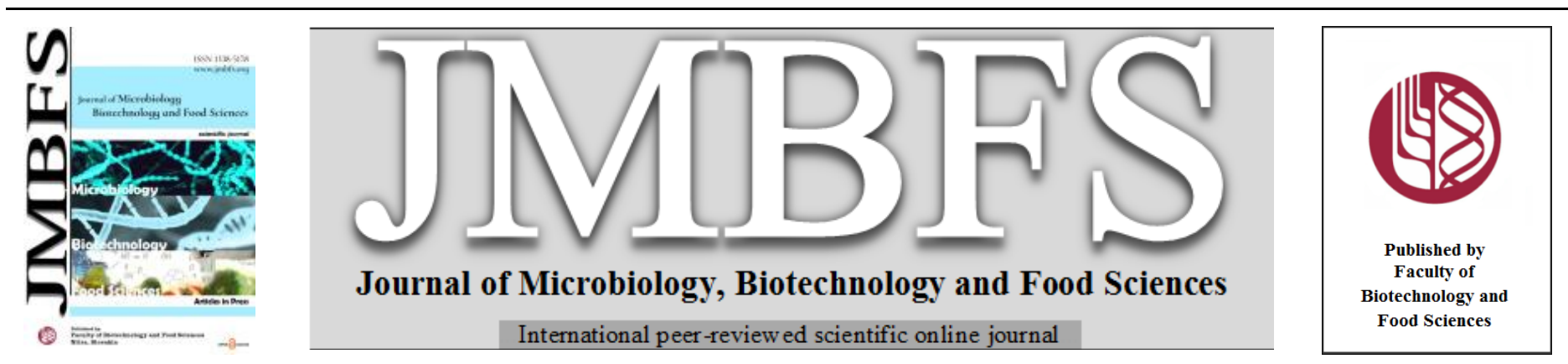

\title{
DEVELOPMENT AND APPLICATION OF ANTIOXIDANT COATING ON Fragaria spp. STORED UNDER ISOTHERMAL CONDITIONS
}

\author{
Sarah Finardi ${ }^{1}$, Tuany Gabriela Hoffmann ${ }^{1}$, Betina Louise Angioletti ${ }^{1}$, Eduarda Mueller ${ }^{1}$, Raissa Souza Lazzaris ${ }^{1}$, Sávio Leandro \\ Bertoli $^{1}$, Miroslava Hlebová ${ }^{2}$, Mars Khayrullin $^{3}$, Natalia Nikolaeva $^{3}$, Mohammad Ali Shariati $^{3,}$, Carolina Krebs de Souza ${ }^{1 *}$
}

\section{$\operatorname{Address(es):~}$}

${ }^{1}$ University of Blumenau, Department of Chemical Engineering, 89030-000, Blumenau, Santa Catarina, Brazil.

${ }^{2}$ University of SS. Cyril and Methodius, Department of Biology, Faculty of Natural Sciences, Nám. J. Herdu 2, SK-91701 Trnava, Slovak Republic.

${ }^{3}$ K.G. Razumovsky Moscow State University of technologies and management (The First Cossack University), 73, Zemlyanoy Val St., Moscow, 109004, Russian Federation.

*Corresponding author: carolinakrebs@ furb.br ; shariatymohammadali@gmai.com

\section{ARTICLE INFO}

Received 23. 6. 2021

Revised 12. 10. 2021

Accepted 19. 10. 2021

Published 1. 2. 2022

$\underline{\text { Regular article }}$ open 2 access

\begin{abstract}
Strawberry (Fragaria spp.) is a non-climacteric fruit, widely consumed in several countries, but is extremely sensitive and susceptible to mechanical damage during harvest, transport and storage, reducing the shelf life. In order to prolong the shelf life of this product, edible starch-based coatings were developed, with propolis extract (MSP) and without the addition of ethanolic propolis extract (MS) and uncoated samples, used as control (MC). All samples were stored under isothermal conditions $\left(4{ }^{\circ} \mathrm{C} \pm 0.5{ }^{\circ} \mathrm{C}\right)$, for 10 days. Physicochemical analyzes ( $\mathrm{pH}$, mass variation, vitamin $\mathrm{C}$, color and phenolic compounds) were carried out to characterize and identify the coating efficiency in the conservation of strawberries. The formulations of the coatings with and without the addition of propolis had a significant $(\mathrm{p} \leq 0.05)$ effect on the variation of fruit weight. The propolis coating showed greater stability in the vitamin $\mathrm{C}$ content and $\mathrm{pH}$ levels, up to the $10^{\text {th }}$ day of cold storage, in comparison to the samples with starch coating and the control. The treatments (MS, MSP and MC) did not significantly influence $(\mathrm{p}>0.05)$ the color and the content of total polyphenols.
\end{abstract}

\section{INTRODUCTION}

Strawberry (Fragaria spp.) is a non-climacteric fruit, among the most consumed in the world (Thomas et al., 2016; Schmitz et al., 2019). Despite having several nutritional components, such as vitamins (A, C, E, B5 e B6), anthocyanins and minerals (Calcium, Iron, Magnesium, Potassium and Selenium), important for a healthy diet, with several health benefits, strawberry is a fruit sensitive to mechanical damage, during harvest, and high senescence in the post-harvest storage (Martínez-González et al., 2020; Hoffmann et al., 2021a). For this reason, preservation technologies, combined with refrigeration systems, are needed to expand the shelf life of strawberries (Garcia et al., 2012; Angioletti $\boldsymbol{e}$ al., 2020a; Pavinatto et al., 2020; Finardi et al., 2021; Hoffmann et al., 2021b). Edible coatings are technologies developed to slow down the decay process of fresh food produce. A thin coating layer, produced from edible materials (protein and polysaccharides) (Roy \& Rhim, 2021), with plasticizing capacity, provides the shelf-life extension of coated food (Fakhouri et al., 2015). The edible coating works by preventing moisture loss from the food to the environment and reducing the oxidative process (Khodaei \& Hamidi-Esfahani, 2019). In addition, gas exchange between the food and the environment is also controlled (Wong $\boldsymbol{e t}$ al., 1994), which maintain the firmness and delay the senescence of fresh fruit and vegetables (Mannozzi et al., 2017).

Starch is a natural biopolymer, based on amylose and amylopectin, widely used in edible film/coating formulations, due to its low cost, easy handling and complete biodegradability (Hoffmann et al., 2019; Hoffmann et al., 2021c). In order to enhance the coating effect, active compounds (antioxidants and/or antimicrobials) can be added to the coating solution (Khodaei \& Hamidi-Esfahani, 2019) Coatings containing active compounds can provide antimicrobial and antioxidant properties to coated foods, contributing to an increase in their shelf life (Angioletti et al., 2020b). Several researchers confirmed the positive effects of the addition of active compounds in food coatings, such as propolis extract (Ali et al., 2014), chitosan and lemon essential oil (Perdones et al., 2012), and potassium sorbate (Garcia et al., 2012).
Propolis is a viscous resin produced by bees (Apis mellifera $\mathrm{L}$.), composed of $50 \%$ resin (containing flavonoids, phenolic acids and esters), $30 \%$ waxes, $10 \%$ essential oils and 5\% pollen (Pastor et al., 2011). This composition is directly dependent on geographic origin, time of collection and climatic conditions (Vasilaki et al., 2019). Propolis possess antimicrobial and antioxidant properties, in other words, possess the ability to donate electrons to free radicals, reducing them to more stable and non-reactive species, protecting food against oxidation (Thomas et al., 2016) Edible coating, using propolis extract, are able to prolong the shelf-life of postharvest fruits, such as pitaya, papaya and strawberry, improving their physicochemical properties (Zahid et al., 2013; Barrera et al., 2015; Thomas et al., 2016).

In the light of these considerations, this study aimed to investigate the influence of an edible coating, produced with starch, glycerol, water and the addition of propolis extract, on the quality of fresh hydroponic strawberries, during the post-harvest storage period (10 days), in a refrigerated environment $\left(4{ }^{\circ} \mathrm{C} \pm 0.5^{\circ} \mathrm{C}\right)$.

\section{MATERIAL AND METHODS}

\section{Material}

The materials used, for the edible coating development and their respective physicochemical analyzes, were: ethyl alcohol (Reatec, CAS [64-17-5]), green propolis alcoholic extract (Apis Flora, CAS N/A), oxalic acid (Anidrol, CAS [144 62-7]), starch (Dinâmica, CAS [9005-25-8]), glycerol (Dinâmica, CAS [56-81-5]), 2,6-dichlorophenol indophenol (Dinâmica, CAS [6520-45-1]), sodium carbonate (Anidrol, CAS [144-55-8]), sodium carbonate (Reatec, CAS [497-19-8]) and Folin-Ciocalteu reagent (Alphatec, CAS N/D).

\section{Propolis coating production}

For the development of the edible coating, propolis active compounds (MSP), starch, glycerol, propolis alcoholic extract and distilled water were used. The solution was prepared using starch $(5 \% \mathrm{~m} / \mathrm{v})$, glycerol $(1.5 \% \mathrm{v} / \mathrm{v})$, as described by 
Hoffmann et al. (2021c), with slight modifications; and extract (3\% v/v). Starch gelatinization was carried out to obtain a thermoplastic starch, in this procedure, the soluble starch was initially heated $\left(52{ }^{\circ} \mathrm{C}\right)$ in a thermostatic bath under mechanical manipulation for 15 minutes, with the addition of glycerol and distilled water. Then the temperature was increased to $82{ }^{\circ} \mathrm{C}$ and maintained for 50 minutes to complete gelatinization and form the filmogenic solution. After cooling the solution, half of the total coating solution generated was transferred and added the propolis extract. Coating formulation without propolis addition (MS), was developed and studied, as well as uncoated samples (control: MC), for comparison purposes.

\section{Coating application on strawberries (Fragaria ssp.)}

Strawberries $(3 \mathrm{~kg})$ with greater color homogeneity, size similarity and withou apparent damage on their surface were selected, in a hydroponic, located in Indaial, Santa Catarina, Brazil. After harvesting, the strawberries were transported in a thermal container to LabFood (Campus II / University of Blumenau). The samples were sanitized, with the aid of a brush, to remove dirt from the strawberries surface. The strawberries were submerged in the film-forming solution, for 5 seconds: strawberries coated with plasticizer solution (MS) and strawberries coated with the film-forming solution, with propolis extract addition (MSP). Still, uncoated strawberries (MC: control condition) were used. After the coating was dried at a constant temperature, $20^{\circ} \mathrm{C} \pm 1{ }^{\circ} \mathrm{C}(24 \mathrm{~h})$, the samples were stored in a refrigerator (TE-371, Tecnal), as showed in Figure 1, at constant temperature and relative humidity, $4{ }^{\circ} \mathrm{C}$ e $60 \%$, respectively, for 10 days.

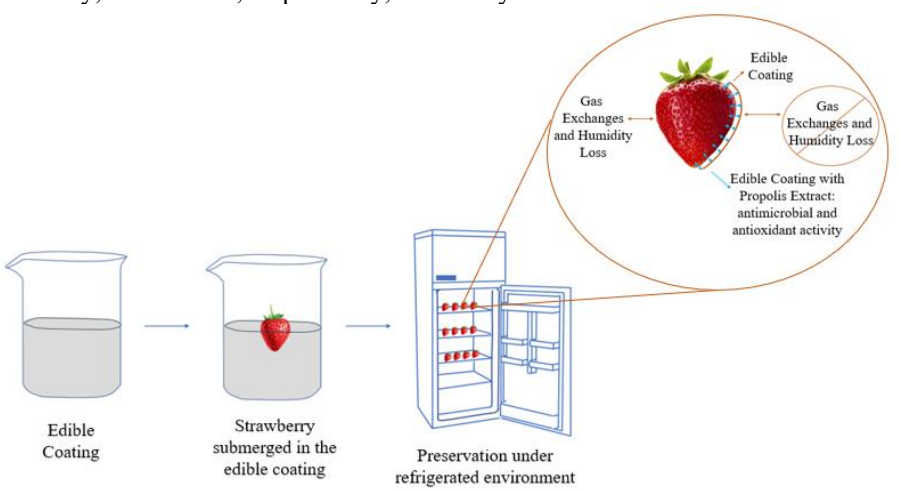

Figure 1 Coating application process and effect on strawberries.

\section{Fresh mass variation}

The fresh mass variation of the samples was measured on a scale (A1000, Marte) and the results were expressed as a percentage (\%), according to equation (1):

$$
M S(\%)=100-\left(\frac{C M}{M 0}\right) * 100
$$

$M S$ is the fresh mass variation percentage, $C M$ is the current mass, in grams $(\mathrm{g})$ and $M 0$ is the mass on the first day, in grams (g).

\section{Quantification of vitamin C}

The vitamin $\mathrm{C}$ content was quantified by titration, with 2,6-dichloroindophenol, according to AOAC (2000). The vitamin $\mathrm{C}$ extraction, from the samples, was performed with oxalic acid (1\%), according to Zhang, Zhang and Yang (2015). The results are expressed in $\mathrm{mg}$ of ascorbic acid per $100 \mathrm{~g}$ of dry mass.

\section{Color analysis}

The color was measured in the CIE-Lab, where $\mathrm{L}^{*}$ is luminosity, $\mathrm{a}^{*}$ is red to green coordinate and $b^{*}$ is yellow to blue coordinate. To this end, a sphere spectrophotometer (SP30, Lovibond) was used. The analyzes were carried out on the samples color homogeneity points. To calculate the luminosity index (LI) and the red index (RI), Equations 2 and Equations 3 were used, respectively.

$$
L I=1-\left(\frac{L^{*}}{L 0^{*}}\right)
$$

$L^{*}$ is the luminosity on the reading day and $L 0^{*}$ is the luminosity of the first day of storage.

$$
R I=1-\left(\frac{a^{*}}{a 0^{*}}\right)
$$

Where $a^{*}$ is red to green coordinate, on the analysis day, and $a 0^{*}$ is red to green coordinate on the first day of storage.

\section{Determination of $\mathbf{p H}$}

To the $\mathrm{pH}$ reading, $1 \mathrm{~g}$ of the sample was ground and diluted in $29 \mathrm{~mL}$ of distilled water. The $\mathrm{pH}$ was measured with the aid of a $\mathrm{pH}$ meter (Tec-3MP, Tecnal), at room temperature $\left(25^{\circ} \mathrm{C}\right)$.

\section{Total phenolic compounds}

The total phenolic compounds determination was carried out according to the Folin-Ciocauteu method (Šamec et al., 2016). For quantification, $5 \mathrm{~g}$ of pulp samples (crushed), stirred in ethylic solution (96\% v/v), were used. Firstly, $0.1 \mathrm{~mL}$ of the pulp solution was transferred to a test tube, with $0.2 \mathrm{~mL}$ of Folin-Ciocauteu reagent and $2 \mathrm{~mol}$ of distilled water. After 3 minutes of rest, $1 \mathrm{~mL}$ of calcium carbonate was added to the solution, to reach the blue color. The samples total polyphenols quantification was performed in a spectrophotometer (Cirrus $80 \mathrm{ST}$, Femto), at a wavelength of $765 \mathrm{~nm}$, and compared to the standard curve, which was developed using a standard solution of gallic acid. The concentration results are expressed in $\mathrm{mg}$ of gallic acid per $100 \mathrm{~g}$ of fresh fruit.

\section{Statistical analysis}

The fresh mass variation analyzes, vitamin $\mathrm{C}$, color, $\mathrm{pH}$ and total phenolic compounds were carried out in triplicate and the results were statistically evaluated using the software Statistica (version 7.0, StatSoft Inc., Tulsa, USA). The results obtained, during the 10 days of storage were evaluated at a $5 \%(\mathrm{p} \leq 0.05)$ level of significance, by one-way analysis of variance (ANOVA) and with Tukey's test.

\section{RESULTS AND DISCUSSION}

\section{Fresh mass variation}

In Figure 2, it is possible to observe the fresh mass variation of strawberries, over the 10 days of storage. Continuous mass loss was observed in all treatments, however, the edible coating, with the addition of propolis (MSP), showed a more satisfactory result in mass stability, with a reduction of $31.76 \%$, after 10 days of storage, followed by MS treatment (38.12\% mass reduction) and MC, with $60.18 \%$ reduction, compared to the first day of storage. The MSP treatment retained $29.05 \%$ more mass than the control, presenting a statistically significant difference $(p \leq 0.05)$. The samples treated with MS, had significant differences $(p \leq 0.05)$, compared to $\mathrm{MC}$, retaining $22.69 \%$ more mass than the control. In addition, the three treatments obtained excellent linear approximation (Table 1), as already reported by Hoffmann et al. (2021a) and Hoffmann et al. (2021b), when evaluating the cold storage of strawberries and other fresh food produce. For this reason, the high MC angular coefficient value, explains the fast mass loss in the control samples (with no coating).

Table 1 Trendline equation and $\mathrm{R}^{2}$ values of treatments (MC, MS e MSP)

\begin{tabular}{ccccccc}
\hline & \multicolumn{3}{c}{ Trendline } & \multicolumn{3}{c}{$\mathbf{R}^{2}$} \\
\cline { 2 - 7 } & MSP & MS & MC & MSP & MS & MC \\
\hline Mass variation & $\mathrm{y}=3.57 \mathrm{x}-3.91$ & $\mathrm{y}=4.24 \mathrm{x}-3.90$ & $\mathrm{y}=6.71 \mathrm{x}-4.77$ & 0.999 & 0.999 & 0.993 \\
\hline
\end{tabular}




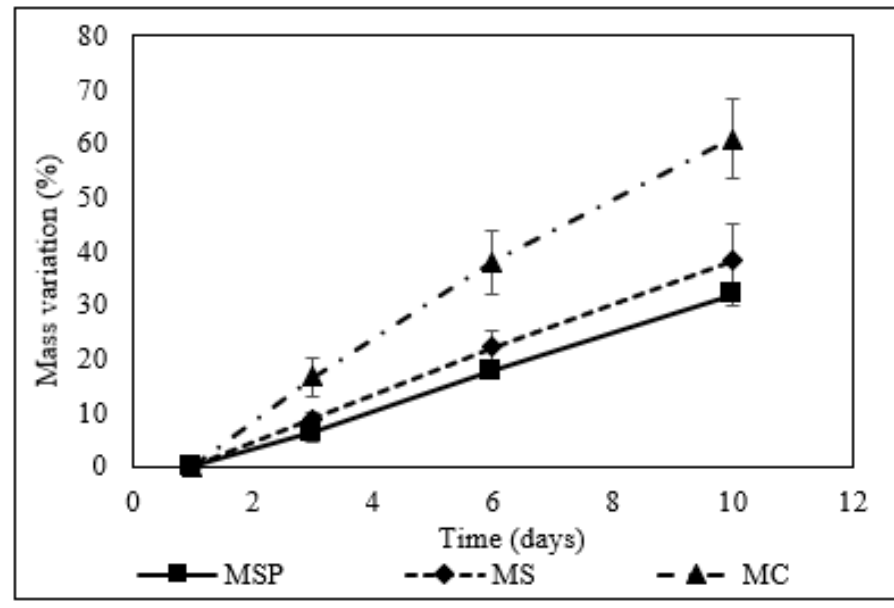

Figure 2 Strawberry mass variation treated with starch and propolis (MSP), starch (MS) and control (MC)
The coating on the strawberry, acted as a barrier for mass transfer, preventing the food from transferring moisture to the environment. Similar behavior was observed by Garcia $\boldsymbol{e t}$ al. (2012), in tests with cassava starch coating (3\%) and potassium sorbate $(0.05 \%)$, on minimally processed strawberries, which showed a smaller reduction in mass loss, (approximately $2.4 \%$ ), at the end of storage. This result is in response to the coating presence, where the water permeation from the fruit to the environment was reduced. Colla et al. (2006) found a maximum mass loss reduction, of approximately $23 \%$ in strawberries coated with a biodegradable edible coating, after 18 days of storage. Different from MC, the MSP and MS presented reduced mass loss due to coating presence. However, the MSP and MS treatments did not show a statistical difference $(p>0.05)$, concerning the propolis addition.

\section{Quantification of vitamin C}

Table 2 shows the vitamin $\mathrm{C}$ behavior, in strawberry samples, under preservation conditions (MS, MC e MSP), in this study. Statistically significant differences (p $\leq 0.05$ ), in the vitamin C reduction, were observed in MSP and MS treatments, during the 10 days of storage. The MSP treatment showed higher vitamin C retention, over time than the other treatments, which can be explained by the fact that the coating differs in gas permeability, resulting in a greater vitamin $\mathrm{C}$ retention (Mditshwa et al., 2017).

Table 2 Vitamin C strawberry content under different preservation conditions (MC, MS e MSP), during 10 days of storage

\begin{tabular}{ccccc} 
& \multicolumn{4}{c}{ Vitamin C (mg/100 g de fresh mass) } \\
\cline { 2 - 5 } & Day 1 & Day 3 & Day 6 & Day 10 \\
\hline MC & $1430 \pm 156.96^{\mathrm{a}}$ & $1287.2 \pm 70.43^{\mathrm{a}}$ & $1227.8 \pm 223.56^{\mathrm{a}}$ & $670.5 \pm 72.55^{\mathrm{ab}}$ \\
MS & $1419.8 \pm 83.79^{\mathrm{a}}$ & $1077.9 \pm 221.7^{\mathrm{a}}$ & $1354 \pm 179.02^{\mathrm{a}}$ & $587.6 \pm 88.82^{\mathrm{b}}$ \\
MSP & $1405.4 \pm 54.45^{\mathrm{a}}$ & $1335.4 \pm 93.75^{\mathrm{a}}$ & $1335.4 \pm 120.08^{\mathrm{a}}$ & $902.1 \pm 149.93^{\mathrm{a}}$ \\
\hline Different lowercase letters denote a significant difference between the rate values in a column $(\mathrm{p} \leq 0.05)$.
\end{tabular}

Hong et al. (2012) observed a slower behavior in decreasing vitamin C content, in coated samples with 1.0 and $1.2 \%$ chitosan, showing approximately $13 \%$ and $10.7 \%$ reduction, at the end of storage, respectively. Vitamin C is one of the most important components in food and directly affects the nutritional quality factor of strawberries (Koyuncu \& Dilmaçünal, 2010), as it is a fundamental antioxidant in citrus fruit. However, the content can be influenced by several factors, such as storage, post-harvest treatment and water loss, which accelerates the reduction of this vitamin C content (Mditshwa et al., 2017).

\section{Color analysis}

The luminosity indices and red indices, of the analyzed samples, did not show significant differences $(p>0.05)$ between them, during the 10 days of storage. The control (MC) showed less luminosity and red index reduction (Table 3), demonstrating that the treatment with propolis was the one that best preserved the color, related to the first day of storage.

Table 3 Luminosity index (LI) and red index (RI) in strawberries, subjected to treatments (MC, MS e MSP).

\begin{tabular}{ccccc|cccc}
\hline & \multicolumn{5}{c}{ LI } & \multicolumn{4}{c}{ RI } \\
\cline { 2 - 9 } & Day 1 & Day 3 & Day 6 & Day 10 & Day 1 & Day 3 & Day 6 & Day 10 \\
\hline MC & $0.00 \pm 0.00^{\mathrm{a}}$ & $0.05 \pm 0.02^{\mathrm{a}}$ & $0.07 \pm 0.04^{\mathrm{a}}$ & $0.08 \pm 0.08^{\mathrm{a}}$ & $0.00 \pm 0.00^{\mathrm{a}}$ & $0.03 \pm 0.03^{\mathrm{a}}$ & $0.16 \pm 0.20^{\mathrm{a}}$ & $0.11 \pm 0.15^{\mathrm{a}}$ \\
MS & $0.00 \pm 0.00^{\mathrm{a}}$ & $0.03 \pm 0.02^{\mathrm{a}}$ & $0.10 \pm 0.04^{\mathrm{a}}$ & $0.10 \pm 0.04^{\mathrm{a}}$ & $0.00 \pm 0.00^{\mathrm{a}}$ & $0.09 \pm 0.05^{\mathrm{a}}$ & $0.16 \pm 0.01^{\mathrm{a}}$ & $0.25 \pm 0.08^{\mathrm{a}}$ \\
MSP & $0.00 \pm 0.00^{\mathrm{a}}$ & $0.05 \pm 0.02^{\mathrm{a}}$ & $0.07 \pm 0.01^{\mathrm{a}}$ & $0.09 \pm 0.01^{\mathrm{a}}$ & $0.00 \pm 0.00^{\mathrm{a}}$ & $0.08 \pm 0.03^{\mathrm{a}}$ & $0.14 \pm 0.03^{\mathrm{a}}$ & $0.21 \pm 0.07^{\mathrm{a}}$ \\
\hline
\end{tabular}

As presented by Garcia et al. (2012), L*, used to calculate the luminosity index, which represents the fruit darkening coordinate, showed that coated and uncoated strawberries obtained similar results, which indicate that cassava starch-based coating did not exert influence on the fruit brightness. In the study conducted by Valenzuela et al. (2015), the strawberry color was not differentiated by the coating presence, corroborating with studies that demonstrate that the application of plasticizer solutions may cause changes in the coated strawberries opacity (Vargas et al., 2006). Therefore, the results of this study are consistent with those found in the literature, indicating that these coatings do not influence strawberry color maintenance.

\section{Determination of $\mathbf{p H}$}

According to Table 4, the $\mathrm{pH}$ of the sample, in the different treatments, shows a continuous tendency to increase, with statistically significant differences $(\mathrm{p} \leq 0.05)$ between the samples over time, due to fungi growth. Strawberries coated with propolis (MSP) showed greater $\mathrm{pH}$ stability, reducing significant changes over time.
Table 4 Strawberry $\mathrm{pH}$ variation in different treatments (MC, MS and MSP) during 10 days of storage

\begin{tabular}{ccccc} 
& \multicolumn{4}{c}{$\mathrm{pH}$} \\
\cline { 2 - 5 } & Day 1 & Day 3 & Day 6 & Day 10 \\
\hline MC & $3.55 \pm 0.021^{\mathrm{a}}$ & $3.59 \pm 0.015^{\mathrm{a}}$ & $3.72 \pm 0.015^{\mathrm{b}}$ & $3.76 \pm 0.025^{\mathrm{b}}$ \\
MS & $3.52 \pm 0.026^{\mathrm{a}}$ & $3.55 \pm 0.035^{\mathrm{a}}$ & $3.72 \pm 0.036^{\mathrm{b}}$ & $3.77 \pm 0.006^{\mathrm{b}}$ \\
MSP & $3.54 \pm 0.012^{\mathrm{a}}$ & $3.58 \pm 0.010^{\mathrm{a}}$ & $3.64 \pm 0.010^{\mathrm{a}}$ & $3.68 \pm 0.015^{\mathrm{a}}$
\end{tabular}

Different lowercase letters denote a significant difference between the rate values in a column $(\mathrm{p} \leq 0.05)$.

The $\mathrm{pH}$ values are associated with changes in the organic acid content of fresh fruit, during storage (Jiang et al., 2020). Alharaty and Ramaswamy (2020) analyzed the influence of sodium alginate-calcium chloride edible coating, applied on strawberries, and observed a significant increase in the $\mathrm{pH}$ of the contro samples, while the coated samples did not show important changes during storage. 


\section{Total phenolic compounds}

The phenolic compounds content in MC (control) samples showed a statistically significant difference $(\mathrm{p} \leq 0.05)$ on the third day, concerning the other samples, stored at $4{ }^{\circ} \mathrm{C}$. However, all samples showed an increase in the phenolic compounds content (Table 5), with interesting results in the MSP sample (with propolis).

Table 5 Phenolic compounds content in strawberries during storage at constant temperature $\left(4^{\circ} \mathrm{C}\right)$.

Phenolic compounds (mg gallic acid/100 g fresh fruit)

\begin{tabular}{ccccc} 
& Day 1 & Day 3 & Day 6 & Day 10 \\
\hline MC & $160.26 \pm 4.55^{\mathrm{a}}$ & $185.15 \pm 2.90^{\mathrm{b}}$ & $175.01 \pm 10.99^{\mathrm{a}}$ & $177.69 \pm 0.97^{\mathrm{a}}$ \\
MS & $155.66 \pm 3.12^{\mathrm{a}}$ & $166.75 \pm 3.11^{\mathrm{a}}$ & $162.72 \pm 4.32^{\mathrm{a}}$ & $178.41 \pm 4.89^{\mathrm{a}}$ \\
MSP & $164.25 \pm 4.83^{\mathrm{a}}$ & $161.15 \pm 0.82^{\mathrm{a}}$ & $175.66 \pm 3.64^{\mathrm{a}}$ & $179.25 \pm 2.63^{\mathrm{a}}$ \\
\hline
\end{tabular}

Different lowercase letters denote a significant difference between the rate values in a column $(\mathrm{p} \leq 0.05)$.

Strawberries have phenolic compounds in the form of anthocyanins, which in turn are responsible for their red color (Aaby, Ekeberg \& Skrede, 2007). Furthermore, phenolic compounds are classified as secondary fruit metabolites (Haminiuk $\boldsymbol{e}$ al., 2012). According to Apriyanti et al. (2018), strawberries coated with green tea extract and chitosan coating obtained an increase in the content of phenolic compounds Similarly, Petriccione et al. (2015) verified that strawberries samples coated with chitosan and refrigerated storage, showed constant results of phenolic compounds, over the storage.

\section{CONCLUSION}

Strawberry samples (MSP and MS) showed results that prove efficiency in reducing mass loss compared to uncoated strawberries. Strawberries coated with starch formulation and added propolis (MSP) showed better results in vitamin C content and stability of $\mathrm{pH}$ values, during storage. The coatings did not influence the color values and total phenolic compounds. In general, it was verified that the coating with the propolis addition $(3 \%)$ is a promising and sustainable alternative for extending the shelf life of strawberries.

Acknowledgments: The authors are grateful for the financial support from Cordination of Superior Level Staff Improvement - CAPES (finance code 001) and Foundation for Research and Innovation of the State of Santa Catarina FAPESC (TO 2018TR342).

\section{REFERENCES}

Aaby, K., Ekeberg, D., \& Skrede, G. (2007). Characterization of phenolic compounds in strawberry (Fragaria $\times$ ananassa) fruits by different HPLC detectors and contribution of individual compounds to total antioxidant capacity Journal of Agricultural and Food Chemistry, 55(11), 4395-4406 https://doi.org/10.1021/jf0702592

Alharaty, G., \& Ramaswamy, H. S. (2020). The effect of sodium alginate-calcium chloride coating on the quality parameters and shelf life of strawberry cut fruits. Journal of Composites Science, 4(3), Article 123 https://doi.org/10.3390/jcs4030123

Ali, A., Chow, W. L., Zahid, N., \& Ong, M., K. (2014). Efficacy of propolis and cinnamon oil coating in controlling post-harvest anthracnose and quality of chill (Capsicum annuиm L.) during cold storage. Food Bioprocess Technology, 7(9), 2742-2748. https://doi.org/10.1007/s11947-013-1237-y

Angioletti, B. L., Pergentino dos Santos, S., Hoffmann, T. G.,Gonçalves, M. J., Fernandes de Carvalho, L., Bertoli, S. L., \& Krebs de Souza, C. (2020a). Influence of whey protein edible film and refrigeration temperature on quality of acerola in natura during postharvest storage. AIChE Annual Meeting.

Angioletti, B. L., Pergentino dos Santos, S., Hoffmann, T. G.,Gonçalves, M. J., Fernandes de Carvalho, L., Bertoli, S. L., \& Krebs de Souza, C. (2020b). Aloe vera gel as a natural additive to improve oxidative stability in refrigerated beef burger stored in aerobic and vacuum packaging. AIChE Annual Meeting.

A.O.A.C. Official methods of analysis. Washington DC: Association of Official Analytical Chemists, 2005.

Apriyanti, D., Rokhati, N., Mawarni, N., Khoiriyah, Z., \& Istirokhatun, T. (2018) Edible coating from green tea extract and chitosan to preserve strawberry (Fragaria vesca L.). In: MATEC Web of Conferences, 156.

Barrera, E., Gil, J., Restrepo, A., Mosquera, K., \& Durango, D. (2015). A coating of chitosan and propolis extract for the postharvest treatment of papaya (Carica Papaya L. cv. Hawaiiana). Revista Facultad Nacional de Agronomía Medellín, 68(2), 7667-7678. https://doi.org/10.15446/rfnam.v68n2.50982
Colla, E., Sobral, P. J. A., \& Menegalli, F. C. (2006). Effect of composite edible coating from amaranthus cruentus flour and stearic acid on refrigerated strawberry (Fragaria ananassa) quality. Latin American Applied Research, 36(4), 249 - 254 Ebadi, Z., Khodanazary, A., Hosseini, S. M., \& Zanguee, N. (2019). The shelf-life extension of refrigerated Nemipterus japonicus fillets by chitosan coating incorporated with propolis extract. International Journal of Biological Macromolecules, 139, 94-102. https://doi.org/10.1016/j.ijbiomac.2019.07.204

Fakhouri, F. M., Martelli, S. M., Caon, T., Velasco, J. I., \& Mei, L. H. I. (2015) Edible films and coatings based on starch/gelatin: Film properties and effect of coatings on quality of refrigerated Red Crimson grapes. Postharvest Biology and Technology, 109, 57-64.

Finardi, S., Hoffmann, T. G., Schmitz, F. R. W., Bertoli, S.L., Khayrullin, M. Neverova, O., Ponomarev, E., Goncharov, A., Kulmakova, N., Dotsenko, E. Khryuchkina, E., Shariati, M.A., de Souza, C.K. Comprehensive Study of LightEmitting Diodes (LEDs) and Ultraviolet-LED Lights Application in Food Quality and Safety. Journal of Pure and Applied Microbiology. 2021;15(3):1125-1135 https://doi.org/10.22207/JPAM.15.3.54.

Garcia, L. C., Pereira, L. M., Sarantópoulos, C. I. G. L., \& Hubinger, M. D. (2012) Effect of antimicrobial starch edible coating on shelf-life of fresh strawberries Packaging Technology and Science, 25(7), 413-425 https://doi.org/10.1002/pts.987

Haminiuk, C. W. I., Maciel, G. M., Plata-Oviedo, M. S. V., \& Peralta, R. M. (2012). Phenolic compounds in fruits - an overview. International Journal of Food Science and Technology, 47(10), 2023-2044. https://doi.org/10.1111/j.1365 2621.2012.03067.x

Hoffmann, T.G., Ronzoni, A.F., da Silva, D.L., Bertoli, S.L., de Souza, C.K. (2021a). Cooling kinetics and mass transfer in postharvest preservation of fresh fruits and vegetables under refrigerated conditions. Chemical Engineering Transactions, 87. https://doi.org/10.3303/CET2187020

Hoffmann, T. G., Ronzoni, A. F., Da Silva, D. L., Bertoli, S. L., \& De Souza, C. K. (2021b). Impact of household refrigeration parameters on postharvest quality of fresh food produce. Journal of Food Engineering, 306, 110641. https://doi.org/10.1016/j.jfoodeng.2021.110641

Hoffmann, T. G., Angioletti, B. L., Bertoli, S. L., \& De Souza, C. K. (2021c) Intelligent $\mathrm{pH}$-sensing film based on jaboticaba peels extract incorporated on a biopolymeric matrix. Journal of Food Science and Technology. https://doi.org/10.1007/s13197-021-05104-6

Hoffmann, T. G., Peters, D. A., Angioletti, B. L., Bertoli, S. L., Péres, L. V., Reiter, M. G. R., \& De Souza, C. K. (2019). Potentials nanocomposites in food packaging. Chemical Engineering Transactions, 75, 253-258 https://doi.org/10.3303/CET1975043

Hong, K., Xie, J., Zhang, L., Sun, D., \& Gong, D. (2012). Effects of chitosan coating on postharvest life and quality of guava (Psidium guajava L.) fruit during

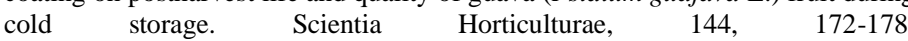
https://doi.org/10.1016/j.scienta.2012.07.002

Jiang, Y., Yu, L., Hu, Y., Zhu, Z., Zhuang, C., Zhao, Y., \& Zhong, Y. (2020). The preservation performance of chitosan coating with different molecular weight on strawberry using electrostatic spraying technique. International Journal of Biological Macromolecules, 151, 278-285. https://doi.org/10.1016/j.ijbiomac.2020.02.169

Khodaei, D., \& Hamidi-Esfahani, Z. (2019). Influence of bioactive edible coatings loaded with Lactobacillus plantarum on physicochemical properties of fresh strawberries. Postharvest Biology and Technology, 156, Article 110944 https://doi.org/10.1016/j.postharvbio.2019.110944

Koyuncu, M. A., \& Dilmaçünal, T. (2010). Determination of vitamin C and organic acid changes in strawberry by HPLC during cold storage. Notulae Botanicae Hort Agrobotanici Cluj-Napoca, 38(3), 95-98. https://doi.org/10.15835/nbha3834819

Mannozzi, C., Cecchini, J. P., Tylewicz, U., Siroli, L., Patrignani, F., Lanciotti, R. Rocculi, P., Dalla Rosa, M., \& Romani, S. (2017). Study on the efficacy of edible coatings on quality of blueberry fruits during shelf-life. LWT - Food Science and Technology, 85(Part B), 440-444. https://doi.org/10.1016/j.1wt.2016.12.056

Martínez-González, M. D. C., Bautista-Baños, S., Correa-Pacheco, Z.N., CoronaRangel, M.L., Ventura-Aguilar, R.I., Del Río-García, J.C., \& Ramos-García M.d.L. (2020). Effect of nanostructured chitosan/propolis coatings on the quality and antioxidant capacity of strawberries during storage. Coatings, 10(2), Article 90. https://doi.org/10.3390/coatings10020090

Mditshwa, A., Magwaza, L. S., Tesfay, S. Z., \& Opara, U. L. (2017). Postharvest factors affecting vitamin $\mathrm{C}$ content of citrus fruits: A review. Scientia Horticulturae, 218, 95-104.

Park, Y. K., Hikegaki, M., Abreu, J. A. S., \& Alcici, N. M. F. (1998). Estudo da preparação dos extratos de própolis e suas aplicações. Ciência e Tecnologia de Alimentos, 18(3), 313-318. https://doi.org/10.1590/S0101-20611998000300011 Pavinatto, A., Mattos, A. V. A., Malpass, A. C. G., Okura, M. H., Balogh, D. T., \& Sanfelice, R. C. (2020). Coating with chitosan-based edible films for mechanical/ biological protection of strawberries. International Journal of Biological Macromolecules, 151, 1004-1011. https://doi.org/10.1016/j.ijbiomac.2019.11.076

Perdones, A., Sánchez-González, L., Chiralt, A., \& Vargas, M. (2012). Effect of chitosan-lemon essential oil coatings on storage-keeping quality of strawberry. 
$\begin{array}{llll}\text { Postharvest Biology } \quad \text { and } & \text { Technology, }\end{array}$ https://doi.org/10.1016/j.postharvbio.2012.04.002

Petriccione, M., Mastrobuoni, F., Pasquariello, M. S., Zampella, L., Nobis, E., Capriolo, G., \& Scortichini, M. (2015). Effect of chitosan coating on the postharvest quality and antioxidant enzyme system response of strawberry fruit during cold storage. Foods, 4(4), 501-523. https://doi.org/10.3390/foods4040501. Roy, S., \& Rhim J. W. (2021). Preparation of gelatin/carrageenan-based colorindicator film integrated with shikonin and propolis for smart food packaging applications. ACS Appl. Bio Mater., 4(1), 770-779. https://doi.org/10.1021/acsabm.0c01353

Šamec, D., Maretić, M., Lugarić, I., Mešić, A., Salopek-Sondi, B., \& Duralija, B (2016). Assessment of the differences in the physical, chemical and phytochemical properties of four strawberry cultivars using principal component analysis. Food Chemistry, 194, 828-834. https://doi.org/10.1016/j.foodchem.2015.08.095

Schmitz, F. R. W., Borgonha, J., Angioletti, B. L., Hoffmann, T. G., Reiter, M. G. R., Bertoli, S. L., Ibsch, R. B. M., \& Krebs de Souza, C. (2019). Influência de sistema de refrigeração não isotérmico sob parâmetros físico-químicos de Fragaria Vesca L. Brazilian Journal of Development, 5(12), 28729-28749.

Thomas, A. B., Nassur, R. C. M. R., Boas, A. C. V., \& Lima, L. C. O. (2016) Cassava starch edible coating incorporated with propolis on bioactive compounds in strawberries. Ciência e agrotecnologia, 40(1), 87-96. https://doi.org/10.1590/S1413-70542016000100008

Valenzuela, C., Tapia, C., López, L., Bunger, A., Escalona, V., \& Abugoch, L. (2015). Effect of edible quinoa protein-chitosan based films on refrigerated strawberry (Fragaria $\times$ ananassa) quality. Electronic Journal of Biotechnology, 18(6), 406-411. https://doi.org/10.1016/j.ejbt.2015.09.001

Vargas, M., Albors, A., Chiralt, A., \& González-Martínez, C. (2006). Quality of cold-stored strawberries as affected by chitosan-oleic acid edible coatings. Postharvest Biology and Technology, 41(2), 164-171. https://doi.org/10.1016/j.postharvbio.2006.03.016

Vasilaki, A., Hatzikamari, M., Stagkos-Georgiadis, A., Goula, A. M., \& Mourtzinos, I. (2019). A natural approach in food preservation: Propolis extract as sorbate alternative in non-carbonated beverage. Food Chemistry, 298, Article 125080. https://doi.org/10.1016/10.1016/j.foodchem.2019.125080

Wong, D. W. S., Tillin, S. J., Hudson, J. S., \& Pavlath, A. E. (1994). Gas exchange in cut apples with bilayer coatings. J. Agríc. Food Chem, 42(10), 2278-2285 https://doi.org/10.1021/jf00046a037

Zahid, N., Ali, A., Siddiqui, Y., \& Maqbool, M. (2013). Efficacy of ethanolic extract of propolis in maintaining postharvest quality of dragon fruit during $\begin{array}{llll}\text { storage. Postharvest Biology and Technology, 79, 69-72. } & \text {. }\end{array}$ https://doi.org/10.1016/j.postharvbio.2013.01.003

Zhang, Y. Z., Zhang, M. L., \& Yang, H. Q. (2015). Postharvest chitosan-g-salicylic acid application alleviates chilling injury and preserves cucumber fruit quality during cold storage. Food Chemistry, 174, 558-563. https://doi.org/10.1016/j.foodchem.2014.11.106 